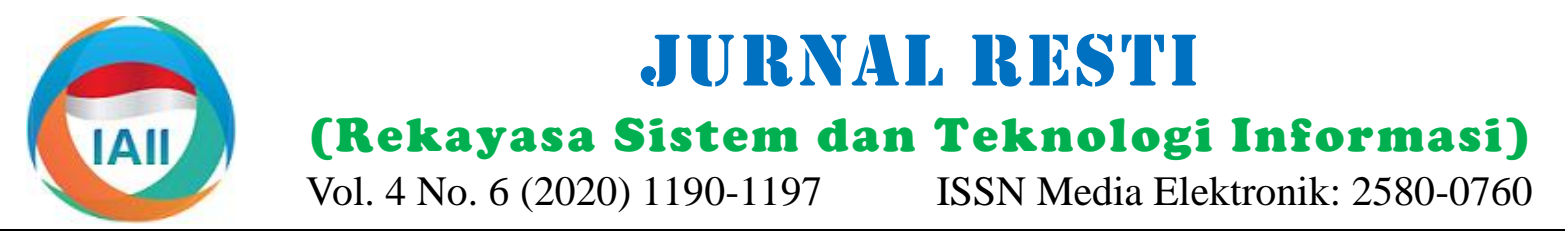

\title{
Implementasi Algoritma Load Balancing PLBA Komputasi Grid pada Lab Environment Menggunakan PVM3
}

\author{
Taufiq Odhi Dwi Putra ${ }^{1}$, Wisnu Widiarto ${ }^{2}$, Wiharto $^{3}$ \\ ${ }^{123}$ Informatika, Universitas Sebelas Maret Surakarta \\ 1taufiq_0dhi_dwi_putra@student.uns.ac.id, ${ }^{2}$ wisnu.widiarto@staff.uns.ac.id*, ${ }^{3}$ wiharto@ staff.uns.ac.id
}

\begin{abstract}
Load balancing is one of the main parts of scheduling Grid resources. One of the load balancing models on Grid resources is the hierarchical model. This model has the advantage that it requires minimal communication costs between one resource and another. The PLBA load balancing algorithm uses a hierarchical model with dynamically obtained threshold values, so that it can adjust conditions at a time, both the state of the resource, the state of the computer network, and the state of the recipient or client. PVM3 is a software system capable of optimizing heterogeneous resources, so that resources can work in parallel. Resources can also complete tasks well, even though they are very large and complex tasks. This research has implemented the PLBA load balancing algorithm, with the aim of optimizing Grid resources. This research has also developed the PLBA load balancing algorithm by changing the arguments for NPEList, so that resources can be grouped more optimally. The PLBA load balancing algorithm has been successfully developed by modifying the arguments for NPEList, so that the running time required to complete the given tasks is shorter, because resources can be grouped more optimally. This has been shown by the shorter average running time when using the modified NPEList argument $(0.75 *$ threshold $1<=A L C i<=1.25 *$ threshold 1$)$ is shorter, than using the NPEList argument in previous research $(A L C i=$ threshold1). Comparison of the average running time has been obtained as follows : (82513.63740: 67837.71720); (63869.92450:50722.17210); (858,96710: 207,33680); (321.88000: 126.89100); (768.54560: 468.27190); (780.22770:279.43730).
\end{abstract}

Keywords: Grid Computing, Load Balancing, Hierarchical Load Balancing Model, Virtual Machine, PVM3

\begin{abstract}
Abstrak
Load balancing adalah salah satu bagian utama pada penjadwalan sumber daya Grid. Salah satu model load balancing pada sumber daya Grid yaitu model hierarki. Model ini memiliki kelebihan yaitu memerlukan biaya komunikasi yang sedikit, antara sumber daya satu dengan sumber daya lainnya. Algoritma load balancing PLBA menggunakan model hierarki dengan nilai threshold yang diperoleh secara dinamis, sehingga dapat menyesuaikan keadaan pada suatu waktu, baik keadaan sumber daya, keadaan jaringan komputer, dan keadaan penerima atau client. PVM3 adalah sistem perangkat lunak yang mampu mengoptimalkan sumber daya yang heterogen, sehingga sumber daya dapat bekerja secara parallel. Sumber daya juga bisa menyelesaikan tasks dengan baik, meskipun tasks tersebut merupakan tasks yang sangat besar dan kompleks. Penelitian ini mengimplementasikan algoritma load balancing PLBA, dengan tujuan untuk mengoptimalkan sumber daya Grid. Penelitian ini juga mengembangkan algoritma load balancing PLBA dengan mengubah argument untuk NPEList, sehingga sumber daya dapat dikelompokkan dengan lebih optimal. Algoritma load balancing PLBA berhasil dikembangkan dengan memodifikasi argument untuk NPEList sehingga running time yang diperlukan untuk menyelesaikan tasks yang diberikan lebih singkat, karena sumber daya dapat dikelompokkan dengan lebih optimal. Hal ini ditunjukkan dengan rata - rata running time pada saat menggunakan argument NPEList yang dimodifikasi $\left(0,75^{*}\right.$ threshold $1<=$ ALCi $<=1,25^{*}$ threshold 1$)$ lebih singkat, daripada menggunakan argument NPEList pada penelitian sebelumnya ( $\mathrm{ALCi}=$ threshold 1$)$. Perbandingan rata-rata running time tersebut adalah sebagai berikut: (82513.63740 : 67837.71720); (63869.92450 : 50722.17210); (858.96710 : 207.33680); (321.88000 : 126.89100); (768.54560: 468.27190); (780.22770: 279.43730).
\end{abstract}

Kata kunci: Grid Computing, Load Balancing, Hierarchical Load Balancing Model, Virtual Machine, PVM3

Diterima Redaksi: 08-11-2020 | Selesai Revisi: 27-12-2020 | Diterbitkan Online: 30-12-2020 


\section{Pendahuluan}

Grid merupakan suatu teknologi yang banyak digunakan suatu perusahaan atau instansi untuk memenuhi Algoritma load balancing PLBA [11], merupakan salah kebutuhan komputasi mereka, karena didukung oleh satu algoritma load balancing dengan pendekatan Tree perkembangan teknologi jaringan di mana based approach dan konsep hierarki yang memungkinkan antara komputer satu dengan komputer mengelompokkan sumber daya menjadi 4 kelompok lainnya dapat bekerja untuk menyelesaikan suatu proses yaitu overloaded, normal, lightly, dan underlightly. yang kompleks secara optimal [1,2,3]. Perkembangan Algoritma ini menggunakan suatu nilai threshold untuk ilmu pengetahuan di bidang teknologi informasi mengelompokkan sumber daya menjadi 4 kelompok membuat kebutuhan komputasi semakin besar. Hal ini tersebut, di mana nilai threshold didapatkan secara disebabkan oleh semakin kompleks proses yang harus dinamis.

diselesaikan karena semakin banyak user yang menggunakan dan kebutuhan user yang dinamis. Oleh karena itu banyak perusahaan atau instansi yang mengandalkan teknologi komputasi grid untuk memenuhi kebutuhan komputasi mereka dikarenakan keterbatasan resource atau sumber daya yang dimiliki.

Salah satu komponen dalam komputasi Grid yaitu load balancing. Load balancing merupakan proses untuk membagi load atau proses ke komputer-komputer yang terhubung [4,5]. Komponen ini merupakan salah satu komponen penting dalam grid, karena untuk load atau proses harus didistribusikan ke komputer-komputer sesuai dengan keadaan dan spesifikasi dari komputerkomputer tersebut, sehingga sumber daya yang ada dapat dioptimalkan secara maksimal[6,7].

Terdapat beberapa algoritma load balancing yang dikembangkan berdasarkan beberapa pendekatan, antara lain Tree based approach, Estimation based approach, Optimization based approach, Agent based approach, Hybrid based approach, Neighbor based approach, Partitioning based approach [8,9]. Masing-masing algoritma mempunyai kelebihan dan kekurangan serta digunakan untuk menyelesaikan masalah tertentu untuk hasil yang paling optimal.

Penelitian-penelitian yang sudah dilakukan, yaitu membandingkan suatu algoritma load balancing dan mengembangkannya, sehingga menghasilkan algoritma baru, serta mencoba membandingkan algoritmaalgoritma tersebut dengan mencobanya pada suatu program simulasi. Program simulasi yang sering digunakan yaitu GridSim atau CloudSim[10]. Mengembangkan algoritma load balancing dengan pendekatan secara hierarki yang berbasis variable threshold value dan diberi nama algoritma PLBA [11]. Mengintegrasikan algoritma load balancing yang dibuat dengan fault-tolerant scheduling yang bernama MinRC dan mengembangkan kemampuan dari algoritma load balancing berbasis fault-tolerant dan diberi nama algoritma PD_MinRC [12]. Mengembangkan algoritma load balancing berdasarkan fault tolerant dan user deadline dan diberi nama algoritma HLBFT [13]. Mengembangkan algoritma load balancing yang dinamis yang menyediakan pengaturan untuk deadline

\section{Metode Penelitian}

Pada bagian ini dijelaskan tentang metode yang digunakan yaitu algoritma load balancing PLBA dan PVM3 (Parallel Virtual Machine) versi 3.

\subsection{Algoritma load balancing PLBA}

Model load balancing pada algoritma PLBA dapat diklasifikasikan menjadi tiga level, yaitu resource, machine, dan PE (Processing Element) [11]. Algoritma PLBA mengeksekusi secara individu pada setiap level, menurut nilai threshold pada setiap level dan algoritma PE level pada level 2. Load sudah dihitung ketika proses datang pada setiap node (komputer) dan terhubung pada masing-masing PE. Proses load balancing yang dilakukan tergantung pada availability dari daftar node yang memiliki load ringan atau agak ringan dan pada saat yang sama node-node tersebut mengirimkan informasi tentang daftar node ini pada setiap komputer. Untuk melakukan proses load balancing, secara acak memilih suatu proses dikirimkan ke node yang memiliki load tinggi atau node yang memiliki load yang rendah. Strategi acak diimplementasikan pada algoritma untuk level machine. Akhirnya, proses perpindahan task dilakukan sampai overload queue tidak kosong dan prosedur yang sama juga diimplementasikan pada level machine dan level resource sebagaimana Gambar 1.

Algoritma PLBA mengelompokkan PE menjadi 4 kelompok yaitu OPEList (Overloaded PE List), NPEList (Normal PE List), LPEList (Lightly Loaded PEList), dan ULPEList (Under Lighly PE List). OPEList adalah PE yang dikategorikan sebagai overload, artinya PE memiliki beban proses yang sangat tinggi, sehingga jika ada task yang ingin diproses pada PE tersebut, maka task akan diproses dengan kurang optimal. NPEList adalah PE yang dikategorikan normal, artinya PE memiliki beban proses yang normal. LPEList adalah PE yang dikategorikan ringan, artinya PE memiliki beban proses yang sedikit. ULPEList adalah PE yang dikategorikan sangat ringan, artinya PE memiliki beban proses yang sangat sedikit. Algoritma ini bertujuan untuk memindahkan tasks yang akan diproses pada PE yang 
termasuk pada OPEList sebanyak mungkin ke PE yang termasuk pada LPEList atau ULPEList.

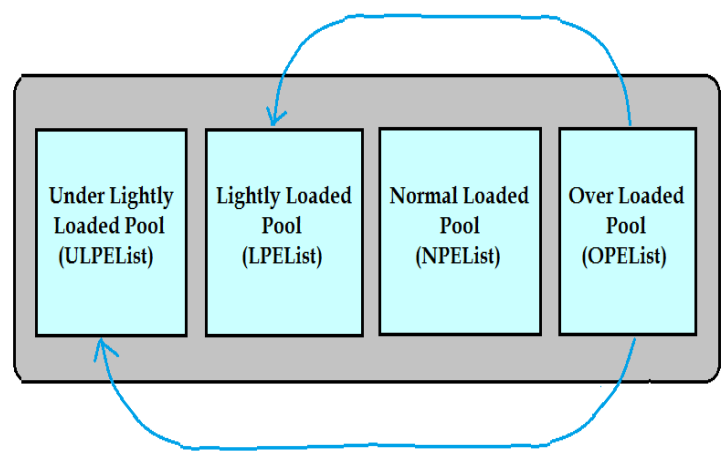

Gambar 1. Metode Penelitian Pemilihan PE Load Balance

Algoritma load balancing PLBA mengelompokkan PE sesuai yang dijelaskan di atas dengan menggunakan nilai threshold yang dinamis sesuai dengan kapan suatu tasks datang dan harus diproses. Nilai threshold [11] tersebut didapatkan dari persamaan (1).

$$
\partial=A L M_{i}+\sigma
$$

Dimana $\partial$ merupakan nilai threshold pertama, ALMi (average load machine system) yaitu rata - rata load pada level machine, dan $\sigma$ adalah standar deviasi dari load pada level machine. Standar deviasi dari load pada level machine dapat dinotasikan pada persamaan (2).

$$
\sigma=\frac{1}{N} \sum_{i=1}^{N}\left(A L C_{i}-A L M\right)^{2}
$$

Dimana $\sigma$ adalah nilai standar deviasi dari load pada level machine, ALM (average load machine system) yaitu rata - rata load pada level machine, dan ALCi (average load cluster) yaitu rata - rata load pada setiap cluster $\mathrm{i}$, dan $\mathrm{N}$ adalah banyaknya cluster pada suatu sistem di level machine. Nilai ALM dapat dihitung dari persamaan (3).

$$
A L M_{i}=\frac{1}{m} \sum_{i=1}^{m} A L C_{i}
$$

Dimana ALMi (average load machine system) yaitu rata - rata load pada level machine, ALCi (average load cluster) yaitu rata - rata load pada setiap cluster, dan $\mathrm{m}$ adalah banyaknya cluster pada suatu sistem di level machine. Nilai ALCi diperoleh dari persamaan (4).

$$
A L C_{i}=\frac{1}{p} \sum_{k=1}^{p} \text { PELoad }_{k, i}
$$

Dimana ALCi (average load cluster) yaitu rata - rata load pada setiap cluster, PELoadk,i adalah load dari semua PE di cluster i, $\mathrm{p}$ adalah jumlah PE di dalam suatu cluster. Nilai PELoadk,i dihitung dari persamaan (5).

$$
\text { PELoad }_{k, i}=\frac{\text { CurrLoad }_{P E}-\text { AvgLoad }}{\text { Rating }}
$$

Dimana PELoadk,i adalah load dari semua (PE)k di cluster i, CurrLoadPE adalah load dari PE saat ini, AvgLoad adalah rata - rata load dari PE, dan Rating adalah kapasitas sebenarnya dari PE seperti kecepatan CPU dalam ketentuan rating MIPS (Million Instructions Per Second). Nilai AvgLoad dapat dihitung dari persamaan (6).

$$
\text { AvgLoad }=\sum_{i=1}^{p}\left(\frac{\text { CurrLoad }_{i}}{p}\right)
$$

Dimana AvgLoad adalah rata - rata load dari PE, CurrLoadi adalah load dari PE saat ini, dan $\mathrm{p}$ adalah jumlah PE di dalam suatu cluster. CurrLoadp dapat dinotasikan pada persamaan (7).

$$
\text { CurrLoad }_{P E}=\sum_{1}^{g} \text { FileSize }
$$

Dimana CurrLoadPE adalah load dari PE saat ini, g adalah jumlah semua tasks di dalam suatu PE, dan FileSize adalah workload dari suatu PE. Kemudian terdapat nilai threshold lainnya yang digunakan untuk menentukan apakah terdapat log yang ditambahkan pada log Overloaded PE. Nilai threshold yang kedua ini didapatkan dari persamaan (8).

$$
\eta=A L R_{i}+\sigma_{1}
$$

Dimana $\eta$ merupakan nilai threshold kedua, ALRi (Average Load of Resource System) yaitu rata - rata load pada level resource, dan $\sigma 1$ adalah nilai standar deviasi untuk threshold kedua. Nilai standar deviasi untuk threshold kedua dapat dinotasikan pada persamaan (9).

$$
\sigma_{1}=\frac{1}{N} \sum_{i=1}^{N}\left(A L M_{i}-A L R\right)^{2}
$$

Dimana $\sigma 1$ adalah nilai standar deviasi untuk threshold kedua, ALMi (average load machine system) yaitu rata - rata load pada level machine, ALR (Average Load of Resource System) yaitu rata - rata load pada level resource, dan $\mathrm{N}$ adalah banyaknya sistem pada level machine. Nilai ALR dapat dihitung dengan persamaan (10).

$$
A L R_{i}=\frac{1}{r} \sum_{i=1}^{r} A L M_{i}
$$

Dimana ALRi (Average Load of Resource System) yaitu rata - rata load pada level resource, ALMi (average load machine system) yaitu rata - rata load pada level machine, dan $r$ adalah banyaknya sistem pada level machine. Langkah-langkah algoritma load balancing PLBA, pada masing-masing level dijabarkan dalam algoritma 1, algoritma 2, algoritma 3 dan algoritma 4 [11]. 


\begin{tabular}{l} 
Algoritma 1: Load Balancing Activity at PE level \\
\hline Deskripsi: Algoritma ini mengeksekusi pada setiap \\
node $(0<=\mathrm{i}<=\mathrm{n})$ \\
Input: daftar proses yang siap untuk dieksekusi \\
Output: Antrian pada daftar PE untuk eksekusi proses \\
\hline 1. Begin \\
2. For (mengecek semua machine pada masing - \\
masing sumber) \\
3. Menunggu aktivitas(seperti perubahan load pada \\
setiap machine) \\
4. If (terdapat aktivitas) \\
5. Memanggil Algorithm 2 untuk mencari kategori \\
6. Plse (contoh OP, UP, LP, NP) \\
7. End if \\
8. End for \\
9. End
\end{tabular}

Algoritma 2: Load calculation algorithm at $P E$ level Deskripsi: Algoritma ini mengeksekusi pada setiap PE sampai PE! $=0$

Input: Ukuran file (sebagai workload pada PE), rating Output: Menghitung load pada setiap PE

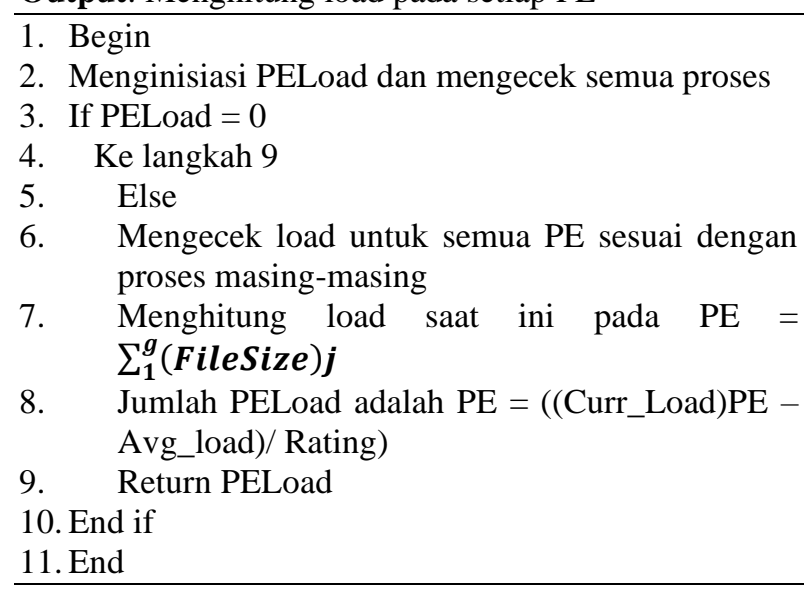

Algoritma 3: Load balancing algorithm at machine level

Deskripsi: Untuk membagi proses load ke dalam daftar PE yang dieksekusi pada semua machine..

Input: nilai threshold, PELoad, Algorithm 2

Output: : Persebaran task sesuai dengan load di semua daftar PE

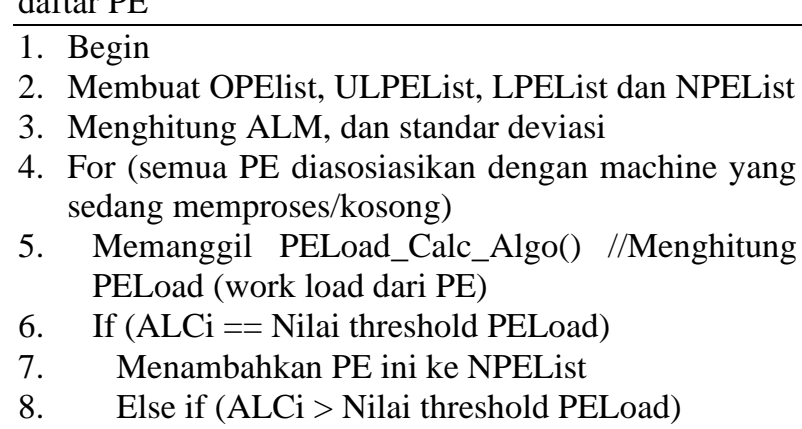

9. Menambahkan PE ini ke OPEList

10. If $\left(\mathrm{ALCi}<0.5^{*}\right.$ Nilai threshold PELoad)

11. Menambahkan PE ini ke ULPEList

12. Else Menambahkan PE ini ke LPEList

13. End if

14. End if

15. End if

16. End for

17. Mengurutkan OPEList secara descending, ULPEList dan LPEList secara ascending terhadap loads

18. Memanggil Algorithm 4

19. End

Algoritma 4: job migration algorithm at machine level Deskripsi: menghitung load untuk proses perpindahan job/tasks.

Input: PE load, Tasks load

Output: Mengirimkan informasi load ke sumber daya pada upper level job migration.

1. Begin

2. For (mengecek PE dari overloaded PE List (descending) dari PE yang dipilih)

3. If (mengecek untuk semua tasks yang diproses atau kosong)

4. Ke langkah 18

5. Else

6. Mengecek untuk semua PE dalam lightly loaded PE list (satu persatu secara ascending)

7. If (menghitung dan mengecek ((PELoad)D + (TaskLoad) $\neg$ L $<0.5^{*}$ Nilai threshold PELoad))

8. Menggeser tasks load dari overload ke lightly loaded PE List

9. Else mengecek untuk semua PE di under lightly loaded PElist (satu persatu secara ascending)

10. If (menghitung dan mengecek ((PELoad)E + (TaskLoad) $\neg L<0.5^{*}$ Nilai threshold PELoad))

11. Menggeser tasks load dari overload ke under lightly loaded PE List

12. Else tasks load dieksekusi di machine semula

13. End if

14. End if

15. End if

16. End for

17. Memanggil Algorithm 3

18. If ((ALCi $>=$ nilai threshold pada level machine) //situasi overload machine

19. Mengirimkan informasi ke level resource untuk perhitungan selanjutnya

20. End if

21. End

2.2. Parallel Virtual Machine versi 3 (PVM3)

PVM3 adalah perangkat lunak yang memungkinkan beberapa komputer yang terhubung ke jaringan dapat digunakan sebagai suatu komputer paralel yang besar [15]. Masalah komputasi yang memerlukan sumber daya 
yang besar dapat diselesaikan dengan beberapa 3. Hasil dan Pembahasan komputer bekerja secara paralel menggunakan perangkat lunak ini [16]. Virtual machine digunakan untuk mengatur persebaran memory dari berbagai komputer. Host digunakan untuk mencatat komputerkomputer yang terhubung dan dapat digunakan untuk mengeksekusi proses.

PVM mendukung berbagai jenis aplikasi dan arsitektur Implementasi percobaan pada tahap ini dilakukan mesin, serta level jaringan. PVM dapat memungkinkan menggunakan 31 virtual machine dengan Oracle VM menjalankan tasks ke mesin dengan arsitektur dan Virtualbox versi 6.1.0. virtual machine yang digunakan aplikasi yang sesuai untuk solusi dari tasks tersebut. terdiri dari 16 virtual machine dengan sistem operasi PVM dapat mengkonversi semua data jika antara dua Ubuntu 18.04.4 LTS dan 15 virtual machine dengan komputer mempunyai integer point atau floating point sistem operasi Debian 10 Buster di mana virtual machine yang berbeda. PVM dapat menghubungkan antar virtual tidak terinstal desktop environment. Konfigurasi untuk machine melalui berbagai tipe jaringan.

Sistem PVM terdiri dari 2 bagian. Bagian pertama yaitu daemon, bernama pvmd3 atau terkadang pada arsitektur tertentu bernama pvmd yang membuat virtual machine pada komputer. Pvmd3 didesain sehingga pengguna dengan autentifikasi yang valid dapat menginstall daemon ini pada komputer. Jika pengguna ingin menjalankan PVM, dia harus membuat virtual machine dengan menjalankan pvmd3 terlebih dahulu. PVM dapat dijalankan di terminal atau command prompt. Banyak pengguna dapat mengkonfigurasi antar virtual machine satu sama lain, dan dapat menjalankan beberapa aplikasi PVM secara simultan. Fitur-fitur yang terdapat pada PVM3 yaitu:

1. User Interface yang diupdate dari versi sebelumnya.

2. Integer Task Identifier, semua proses yang dijalankan pada PVM3 direpresentasikan sebagai Integer Task Identifier.

3. Process Control, PVM menyediakan fitur sehingga proses yang dijalankan dapat menjadi PVM task dan dapat dikembalikan menjadi proses normal lagi.

4. Fault Tolerance, PVM dapat mendeteksi secara otomatis jika terdapat host fails dan menghapus host tersebut dari virtual machine.

5. Dynamic Process Groups, proses dapat dimiliki oleh beberapa group, dan group dapat dapat mengubahnya secara dinamis pada waktu kapan saja saat komputasi sedang berlangsung.

6. Signaling, PVM menyediakan dua cara untuk memberi sinyal kepada PVM tasks lainnya. Cara pertama mengirimkan sinyal UNIX ke task lainnya. Cara kedua yaitu mengirimkan pesan notifikasi dengan tag pengguna tertentu dan aplikasi dapat mengeceknya.

7. Communication, PVM menyediakan siklus untuk mengirim dan menerima pesan antara task satu dengan task lainnya.

8. Multiprocessor Integration, PVM dapat mengintegrasikan komputer satu dengan komputer lainnya dengan tipe dan aristektur yang berbeda tanpa membebankannya kepada perangkat lunak jaringan seperti TCP/IP.
Hasil percobaan implementasi algoritma load balancing PLBA menggunakan PVM3 pada lab Environment dapat dijabarkan dalam 2 hal: Lab. Environment dan Hasil Percobaan Implementasi Program.

\subsection{Lab Environment} setiap virtual machine dibuat sama yaitu $4 \mathrm{CPU}, 4 \mathrm{~Gb}$ RAM, 20 Gb hardisk, dan network adapter jenis Bridged adapter yaitu network interface yang mirip seperti salah satu network interface pada komputer yang menjalankannya serta mendapat ip address yang satu network dengan network interface tersebut. Spesifikasi komputer yang digunakan yaitu CPU 3.10 Ghz x4, RAM $8 \mathrm{~Gb}$, hardisk $1 \mathrm{~Tb}$, dengan sistem operasi Windows 7 . Komputer yang digunakan berjumlah 24 di mana masing - masing komputer menjalankan satu atau dua virtual machine. Konfigurasi jaringan yang digunakan yaitu menggunakan local area network yang dihubungkan interface Gigabit Ethernet.

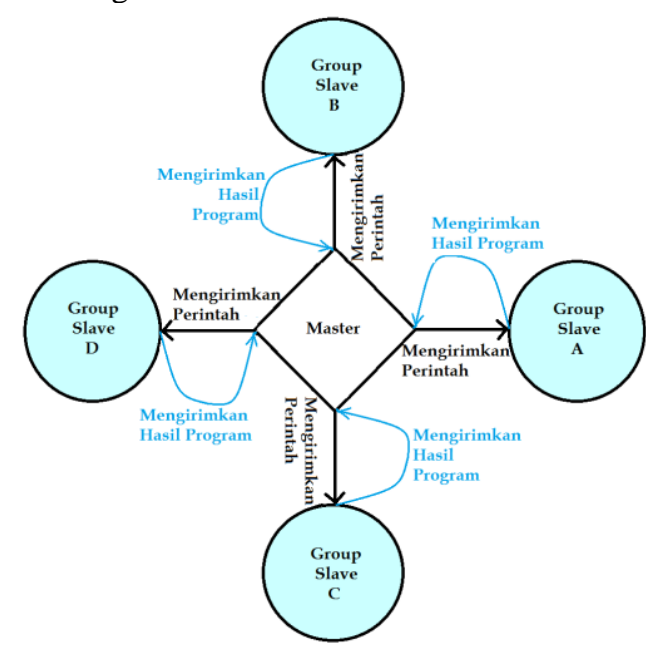

Gambar 2. Ilustrasi Pengujian Implementasi Program

\subsection{Hasil Percobaan Implementasi Program}

Percobaan pada tahap ini yaitu menguji algoritma Load Balancing PLBA dengan menggunakan 3 program yaitu program A, program B, dan Program C. Program A adalah program yang melakukan proses membuat data berupa angka sebanyak 100.000.000 secara acak, kemudian data tersebut diurutkan dengan menggunakan algoritma sorting Merge Sort. Program B adalah program yang melakukan proses membuat data berupa angka sebanyak 1.000.000 secara acak, kemudian data tersebut dijumlahkan semua. 
Tabel 1. Running Time (ms) Percobaan Program A

\begin{tabular}{ccccc}
\hline \multirow{2}{*}{ No. } & \multicolumn{5}{c}{ Argument NPEList } \\
\cline { 2 - 5 } & \multicolumn{2}{c}{ ALC $\mathrm{i}=$ threshold 1} & $0,75^{*}$ threshold $1<$ ALC $_{\mathrm{i}}<=1,25 *$ threshold 1 \\
\cline { 2 - 5 } 1 & 85778.08800 & 66348.00100 & 67794.60300 & 30 Hosts \\
\hline 2 & 96164.64900 & 58215.60500 & 66758.79100 & 45755.21300 \\
3 & 62034.33400 & 66057.35800 & 55829.83900 & 58376.39000 \\
4 & 97337.94800 & 65335.72700 & 67505.78400 & 50177.47300 \\
5 & 99177.46700 & 67202.46200 & 75569.22400 & 47895.97600 \\
6 & 61608.69900 & 64453.51200 & 68690.16300 & 50991.72300 \\
7 & 63971.62400 & 66172.19400 & 68296.71900 & 54360.56800 \\
8 & 97271.09000 & 66456.95100 & 71692.89700 & 52065.33200 \\
9 & 97755.26800 & 64248.14000 & 68054.65100 & 51716.92600 \\
10 & 64037.20700 & 54209.29500 & 68184.50100 & 52501.67900 \\
\hline Rata2 & 82513.63740 & 63869.92450 & 67837.71720 & 43380.44100 \\
\hline
\end{tabular}

Tabel 2. Running Time (ms) Percobaan Program B

\begin{tabular}{|c|c|c|c|c|}
\hline \multirow{3}{*}{ No. } & \multicolumn{4}{|c|}{ Argument NPEList } \\
\hline & \multicolumn{2}{|c|}{$\mathrm{ALC}_{\mathrm{i}}=$ threshold 1} & \multicolumn{2}{|c|}{$0,75^{*}$ threshold $1<=$ ALC $_{\mathrm{i}}<=1,25^{*}$ threshold 1} \\
\hline & 25 Hosts & 30 Hosts & 25 Hosts & 30 Hosts \\
\hline 1 & 776.15400 & 306.44500 & 170.79600 & 128.55300 \\
\hline 2 & 770.19900 & 301.69200 & 186.06200 & 132.37300 \\
\hline 3 & 1724.4660 & 308.70500 & 193.56100 & 127.45700 \\
\hline 4 & 762.25600 & 300.88400 & 171.57000 & 129.15100 \\
\hline 5 & 750.01200 & 302.63600 & 187.84900 & 120.66900 \\
\hline 6 & 759.49500 & 342.42000 & 194.91700 & 133.54400 \\
\hline 7 & 759.41800 & 337.97000 & 190.29000 & 116.21500 \\
\hline 8 & 769.86900 & 341.41800 & 261.29500 & 124.30900 \\
\hline 9 & 761.01500 & 342.86100 & 257.40700 & 131.14400 \\
\hline 10 & 756.78700 & 333.76900 & 259.62100 & 125.49500 \\
\hline Rata2 & 858.96710 & 321.88000 & 207.33680 & 126.89100 \\
\hline
\end{tabular}

Tabel 3. Running Time (ms) Percobaan Program C

\begin{tabular}{ccccc}
\hline \multirow{2}{*}{ No. } & \multicolumn{3}{c}{ Argument NPEList } \\
\cline { 2 - 5 } & \multicolumn{2}{c}{ ALC $_{\mathrm{i}}=$ threshold 1} & $0,75^{*}$ threshold $1<=$ ALC $_{\mathrm{i}}<=1,25 *$ threshold 1 \\
\cline { 2 - 5 } 1 & 25 Hosts & 30 Hosts & 25 Hosts & 30 Hosts \\
\hline 2 & 828.16800 & 759.03800 & 455.88700 & 300.04900 \\
3 & 772.95800 & 708.92500 & 440.77200 & 266.20500 \\
4 & 769.47600 & 715.09400 & 451.21200 & 232.54900 \\
5 & 751.94600 & 711.28300 & 438.99500 & 225.48000 \\
6 & 755.11900 & 738.66000 & 452.12100 & 231.40100 \\
7 & 765.20300 & 773.84800 & 509.80200 & 381.87200 \\
8 & 776.56000 & 754.07800 & 458.05100 & 311.25600 \\
9 & 743.86000 & 1215.77200 & 484.61300 & 285.16500 \\
10 & 711.12300 & 704.54700 & 496.29300 & 287.86400 \\
\hline Rata2 & 768.54560 & 780.22770 & 494.97300 & 272.53200 \\
\hline
\end{tabular}

Jurnal RESTI (Rekayasa Sistem dan Teknologi Informasi) Vol. 4 No. 6 (2020) 1190 - 1197 
Program $\mathrm{C}$ adalah program yang membuat angka yang terdiri dari 7 virtual machine, Group Slave $\mathrm{C}$ terdiri Fibonacci dari ke-1 sampai ke-10.000. Ketiga program dari 9 virtual machine. Percobaan pada tahap ini hanya tersebut dijalankan secara parallel dengan model virtual machine yang berperan sebagai slave saja yang membagi data yang harus dibuat dan diproses sesuai mengerjakan proses yang diberikan, virtual machine dengan jumlah virtual machine yang dihubungkan pada yang berperan sebagai master hanya membagi proses PVM (parallel virtual machine).

Tabel 1 menunjukkan running time menggunakan program A dengan 4 kelompok komputer. Percobaan dilakukan sebanyak 10 kali proses yang dijalankan pada satu kali eksekusi program, dengan running time yaitu:

a) $82513.63740 \mathrm{~ms}$, untuk argument NPEList ALCi $=$ threshold 1 dan jumlah hosts 25 ,

b) $63869.92450 \mathrm{~ms}$, untuk argument NPEList ALCi $=$ threshold 1 dan jumlah hosts 30 ,

c) $67837.71720 \mathrm{~ms}$, untuk argument NPEList $0,75 *$ threshold $1<=$ ALCi $<=1,25 *$ threshold 1 dan jumlah hosts 25 ,

d) $50722.17210 \mathrm{~ms}$, untuk argument NPEList $0,75 *$ threshold $1<=$ ALCi $<=1,25 *$ threshold 1 dan jumlah hosts 30 . dari user dan menggabungkan hasil dari setiap slave dan dikirimkan lagi ke user dalam bentuk output sesuai dengan proses yang diberikan.

Berdasarkan hasil pengujian program dan pada Tabel 1, Tabel 2, dan Tabel 3, pertama argument atau parameter untuk NPEList (Normal PEList) yang diusulkan dapat meningkatkan efisiensi program, karena rata - rata running time program baik program A, B, C lebih singkat ketika menggunakan argument NPEList $0,75^{*}$ threshold $1<=$ ALCi $<=1,25^{*}$ threshold 1 daripada menggunakan argument NPEList sebelumnya yaitu $\mathrm{ALCi}=$ threshold1. Hal ini disebabkan karena ketika menggunakan argument NPEList ALCi $=$ threshold1 maka kondisi tersebut hampir tidak mungkin terpenuhi, sehingga pada semua hasil pengujian menggunakan argument tersebut tidak ada host yang dimasukkan pada

Tabel 2 menunjukkan running time menggunakan NPEList sedangkan ketika menggunakan argument program B dengan 4 kelompok komputer. Percobaan NPEList $0,75 *$ threshold $1<=$ ALCi $<=1,25 *$ threshold 1 dilakukan sebanyak 10 kali proses yang dijalankan pada maka untuk kelompok NPEList tidak selalu kosong. satu kali eksekusi program, dengan running time yaitu:

a) $\quad 858.96710 \mathrm{~ms}$, untuk argument NPEList ALCi $=$ threshold 1 dan jumlah hosts 25 ,

b) $321.88000 \mathrm{~ms}$, untuk argument NPEList ALCi $=$ threshold 1 dan jumlah hosts 30 ,

c) $207.33680 \mathrm{~ms}$, untuk argument NPEList $0,75 *$ threshold $1<=$ ALCi $<=1,25 *$ threshold 1 dan jumlah hosts 25 ,

d) $126.89100 \mathrm{~ms}$, untuk argument NPEList $0,75 *$ threshold $1<=$ ALCi $<=1,25 *$ threshold 1 dan jumlah hosts 30 .

Tabel 3 menunjukkan running time dengan 4 kelompok komputer. Percobaan dilakukan sebanyak 10 kali proses yang dijalankan pada satu kali eksekusi program, dengan running time yaitu:

Beberapa hasil percobaan menunjukkan running time program lebih singkat jika menggunakan argument NPEList ALCi = threshold1, akan tetapi hal ini disebabkan oleh faktor lainnya seperti koneksi jaringan karena virtual machine dijalankan di beberapa komputer sehingga terkadang terjadi bottle neck di jaringan komputer yang digunakan, dan dapat disebabkan juga karena proses - proses lainnya yang sedang berjalan pada waktu yang sama.

Algoritma load balancing PLBA dapat diimplementasikan cukup optimal dengan menggunakan PVM3, karena dapat menggunakan sumber daya yang terdistribusi secara optimal, meskipun sumber daya yang digunakan berjalan pada sistem operasi yang tidak sama semua dan dalam kondisi yang berbeda - beda, yaitu beberapa komputer menjalankan satu virtual machine

a) $768.54560 \mathrm{~ms}$, untuk argument NPEList ALCi $=$ threshold 1 dan jumlah hosts 25 ,

dan beberapa lainnya menjalankan dua virtual machine sekaligus. PVM3 dapat digunakan sebagai media

b) $780.22770 \mathrm{~ms}$, untuk argument NPEList ALCi komunikasi antara sumber daya satu dengan sumber $=$ threshold 1 dan jumlah hosts 30 , daya lainnya dalam suatu sumber daya grid, karena

c) $468.27190 \mathrm{~ms}$, untuk argument NPEList dapat menyelesaikan salah satu masalah dari sumber $0,75 *$ threshold $1<=$ ALCi $<=1,25 *$ threshold 1 daya grid, yaitu sumber daya yang heterogen sehingga dan jumlah hosts 25 ,

perlu adanya sebuah compatibility layer antara sumber

d) $279.43730 \mathrm{~ms}$, untuk argument NPEList daya satu dengan sumber daya lainnya. Ketika terdapat $0,75 *$ threshold $1<=$ ALCi $<=1,25 *$ threshold 1 host yang masuk pada kelompok OPEList selalu dan jumlah hosts 30 .

Pada Gambar 2 menunjukkan ilustrasi pengujian yang dilakukan di lab. Terdapat satu virtual machine yang ditunjuk sebagai master dan sisanya yaitu sebanyak 30 virtual machine berperan sebagai slave. Dari 30 virtual machine akan dibagi menjadi 4 kelompok yaitu Group Slave A yang terdiri dari 8 virtual machine, Group Slave ditambahkan pada log Overloaded PE, sehingga nilai threshold2 dapat digantikan dengan argument, jika OPEList tidak NULL maka log Overloaded PE ditambahkan sesuai dengan jumlah hosts yang ada di OPEList.

\section{Kesimpulan}

B yang terdiri dari 6 virtual machine, Group Slave C Algoritma load balancing PLBA telah berhasil

Jurnal RESTI (Rekayasa Sistem dan Teknologi Informasi) Vol. 4 No. 6 (2020) 1190 - 1197 
diimplementasikan pada lab environment, yaitu [5] Qilin, M. and Weikang, S., 2015, "A Load Balancing Method menggunakan lab komputer sebagai sumber daya Grid, dengan komputer - komputer sebagai sumber daya tersebut. Implementasi algoritma load balancing PLBA menggunakan PVM3, dapat mengoptimalkan sumber daya Grid yang digunakan, untuk menyelesaikan tasks yang diberikan. Algoritma load balancing PLBA juga telah berhasil dioptimalkan, dengan memodifikasi argument untuk NPEList. Hal ini ditunjukkan dengan rata - rata running time dalam menyelesaikan tasks, ketika menggunakan argument NPEList yang dimodifikasi (menggunakan argument NPEList $0,75 *$ threshold $1<=$ ALCi $<=1,25 *$ threshold 1 ) lebih singkat, daripada ketika menggunakan argument NPEList pada penelitian sebelumnya (menggunakan argument NPEList ALCi $=$ threshold1), karena pengelompokkan PE (Process Element) dengan argument NPEList dimodifikasi lebih optimal, daripada dengan menggunakan argument NPEList pada penelitian sebelumnya. Perbandingan rata-rata running time untuk argument NPEList asal dengan argument NPEList modifikasi adalah sebagai berikut: 82513.63740:67837.71720; 63869.92450:50722.17210; 858.96710 : 207.33680; $321.88000: 126.89100$; $768.54560: 468.27190 ; 780.22770: 279.43730$.

\section{Daftar Rujukan}

[1] Buyya, R. and Murshed, M., 2002, "Gridsim: A toolkit for the modeling and simulation of distributed resource management and scheduling for grid computing," Concurrency and Computation: Practice and Experience, vol. 14, no. 13-15, pp. 1175-1220, DOI: $10.1002 / \mathrm{cpe} .710$

[2] Menasce, D.A. and Casalicchio, E., 2004, "A framework for resource allocation in grid computing", In: The IEEE Computer Society's, 12th Annual International Symposium on Modeling, Analysis, and Simulation of Computer and Telecommunications Systems, Volendam, Netherlands, 8-8 Oct. 2004, pp. 259-267, IEEE, DOI: 10.1109/MASCOT.2004.1348280

[3] Prajapati, H.B. and Shah, V.A., 2014, "Scheduling in Grid Computing Environment", In: The Institute of Electrical and Electronics Engineers, Inc., 2014 Fourth International Conference on Advanced Computing \& Communication Technologies, Rohtak, India, 8-9 Feb. 2014, pp. 315-324, IEEE, Conference Publishing Services (CPS), DOI: 10.1109/ACCT.2014.32

[4] Goswami, S. and Sarkar, A.D., 2013, "A comparative study of load balancing algorithms in computational grid environment," In: The Institute of Electrical and Electronics Engineers, Inc., 2013 Fifth International Conference on Computational Intelligence, Modelling and Simulation, Seoul, South Korea, 24-25 Sept. 2013, pp. 99-104, IEEE, Conference Publishing Services (CPS), DOI: 10.1109/CIMSim.2013.24

Qilin, M. and Weikang, S., 2015, "A Load Balancing Method
Based on SDN," In: ICMTMA 2015, 2015 Seventh International Conference on Measuring Technology and Mechatronics Automation, Nanchang, China, 13-14 June 2015, pp. 18-21, IEEE, DOI: 10.1109/ICMTMA.2015.13

[6] Jiao, Y. and Wang, W., 2010, "Design and Implementation of Load Balancing of Distributed-system-based Web Server," In: ISECS 2010, 2010 Third International Symposium on Electronic Commerce and Security, Guangzhou, 29-31 July 2010, pp. 337342, IEEE, DOI: 10.1109/ISECS.2010.81

[7] Ohta, S. and Andou, R., 2009, "WWW server load balancing technique based on passive performance measurement," 2009 6th International Conference on Electrical Engineering/Electronics, Computer, Telecommunications and Information Technology, Pattaya, Chonburi, Thailand, 6-9 May 2009, pp. 884-887, IEEE, DOI: 10.1109/ECTICON.2009.5137187

[8] Patel, D.K., Tripathy, D., and Tripathy, C.R., 2016, "Survey of load balancing techniques for grid," Journal of Network and Computer Applications, vol. 65, pp. 103-119, DOI: 10.1016/j.jnca.2016.02.012

[9] Guan, H., Li, C.K., Cheung, T.Y., Yu, S. and Tong, W., 1996, "Design and implementation of a parallel software for hybrid neural network computation in PVM environment," Proceedings of Third International Conference on Signal Processing (ICSP'96), Beijing, China, 18-18 Oct. 1996, pp. 1421-1424, IEEE, DOI: 10.1109/ICSIGP.1996.566591

[10]Ponciano, J.P. and Anani, N., 2014, "Load balancing in modern network infrastructures - A simulation model", In: CSNDSP, 2014 9th International Symposium on Communication Systems, Networks \& Digital Sign (CSNDSP), Manchester, UK, 23-25 July 2014, pp. 841-846, IEEE, DOI: 10.1109/CSNDSP.2014.6923944

[11]Rathore, N. and Chana, I., 2015, "Variable threshold-based hierarchical load balancing technique in Grid," Engineering with Computers., vol. 31, no. 3, pp. 597-615 DOI: 10.1007/s00366014-0364-z

[12] Balasangameshwara, J. and Raju, N., 2012, "Performance-driven load balancing with a primary-backup approach for computational grids with low communication cost and replication cost," IEEE Transactions on Computers, vol. 62, no. 5, pp. 990-1003, DOI: 10.1109/TC.2012.44

[13]Nanthiya, D. and Keerthika, P., 2013, "Load balancing GridSim architecture with fault tolerance," In: ICICES, 2013 International Conference on Information Communication and Embedded Systems, Chennai, India, 21-22 Feb. 2013, pp. 425-428, IEEE, DOI: 10.1109/ICICES.2013.6508306

[14]Hao, Y., Liu, G., and Wen, N., 2012, “An enhanced load balancing mechanism based on deadline control on GridSim," Future Generation Computer Systems, vol. 28, no. 4, pp. 657-665, DOI: 10.1016/j.future.2011.10.010

[15] Setyawan, H.H., Widiarto, W. dan Wiharto, 2020, "Implementasi Algoritma Improvised Prioritized Deadline Scheduling Algorithm (IPDSA) pada Grid Environment", Jurnal RESTI (Rekayasa Sistem dan Teknologi Informasi), Vol. 4, No. 5, Oktober 2020, pp. 957-963, DOI: doi.org/10.29207/resti.v4i5.2457

16] Sampath, S., Nanjesh, B.R., Sagar, B.B. and Subbaraya, C.K., 2014, "Performance optimization of PVM based parallel applications using optimal number of slaves," In: ICROIT, 2014 International Conference on Reliability Optimization and Information Technology, Faridabad, India, 6-8 Feb. 2014, pp. 388-392, IEEE, DOI: 10.1109/ICROIT.2014.67983 